\title{
Studied of Defatted Flour and Protein Concentrate of Prunus serotine and Applications
}

\author{
Analía A. Lu Martínez ${ }^{1}$, Juan G. Báez González ${ }^{1, * \mathbb{C}}$, Minerva Bautista Villarreal ${ }^{1}$, \\ Karla G. García Alanis ${ }^{1}$, Sergio A. Galindo Rodríguez ${ }^{2}$ and Eristeo García Márquez ${ }^{3, *}$ \\ 1 Universidad Autónoma de Nuevo León, Facultad de Ciencias Biológicas, Departamento de Alimentos, \\ Avenida Universidad s/n, Ciudad Universitaria, San Nicolás de los Garza, NL 66455, Mexico; \\ liamtz18@hotmail.com (A.A.L.M.); minevillareal@hotmail.com (M.B.V.); \\ karla_alanis23@hotmail.com (K.G.G.A.) \\ 2 Universidad Autónoma de Nuevo León, Facultad de Ciencias Biológicas, Laboratorio de Nanotecnología, \\ Avenida Universidad s/n, Ciudad Universitaria, San Nicolás de los Garza, NL 66455, Mexico; \\ sagrod@yahoo.com.mx \\ 3 Centro de Investigación y Asistencia en Tecnología y Diseño del Estado de Jalisco, Autopista \\ Mty-Aeropuerto Km 10 Parque PIIT, Vía de Innovación 404, Apodaca, NL 66629, Mexico \\ * Correspondence: juan.baezgn@uanl.edu.mx (J.G.B.G.); egarcia@ciatej.mx (E.G.M.)
}

Received: 16 November 2019; Accepted: 23 December 2019; Published: 27 December 2019

check for updates

\begin{abstract}
Prunus serotine seed, was processed to produce a defatted flour (71.07 $\pm 2.10 \%$ yield) without hydrocyanic acid. The total protein was $50.94 \pm 0.64 \%$. According to sensory evaluation of cookies with P. serotine flour, the highest score in overall impression (6.31) was at 50\% flour substitution. Its nutritional composition stood out for its protein and fiber contents $12.50 \%$ and $0.93 \%$, respectively. Protein concentrate $\left(P_{S} P C\right)$ was elaborated $(81.44 \pm 7.74 \%$ protein) from defatted flour. Emulsifying properties of $P_{s} \mathrm{PC}$ were studied in emulsions at different mass fractions; $\phi=0.002,0.02,0.1,0.2$, and 0.4 through physicochemical analysis and compared with whey protein concentrate (WPC). Particle size in emulsions increased, as did oil content, and results were reflected in microscope photographs. PsPC at $\phi 0.02$ showed positive results along the study, reflected in the microphotograph and emulsifying stability index (ESI) test $(117.50 \mathrm{~min})$. At $\phi 0.4$, the lowest ESI $(29.34 \mathrm{~min})$, but the maximum emulsifying activity index (EAI) value $\left(0.029 \mathrm{~m}^{2} / \mathrm{g}\right)$ was reached. WPC had an EAI value higher than $P_{s} P C$ at $\phi \geq 0.2$, but its ESI were always lower in all mass fraction values. PsPC can compete with emulsifiers as WPC and help stabilize emulsions.
\end{abstract}

Keywords: Prunus serotine; defatted flour; soluble protein; protein concentrate; emulsifying properties; emulsion stability

\section{Introduction}

Nowadays, there is an increasing demand for products of high nutritional quality [1]. Proteins are one of the major components of the human diet because of their nutritional properties. They are also responsible for physicochemical properties such as solubility, water, and oil retention capacity, foaming and emulsifying capacity, viscosity, and gelation, among others. The proteins impact not only the quality of the products, but also acceptance by consumers [2]. 
Protein is available in a variety of dietary sources [3]. In recent years, the growing concern of consumers with respect to animal safety has forced the industry to use vegetable proteins [4-6]. This type of proteins has health benefits, e.g., reduction of blood cholesterol levels, prevention of obesity and lower risk of heart diseases and cancer [7]. Vegetable proteins, when mixed with cereals, provide an alternative source of amino acids [3], which is why enrichment of other protein sources such as oilseeds and legumes with cereal-based foods has received considerable attention [8].

Baked snacks, such as bread and cookies, are widely accepted and consumed throughout the world and have become an attractive target for feeding and nutritional status improvement programs. This is especially true for cookies, because they not only offer a good vehicle for protein enrichment for consumers, but also because of their wide-spread consumption (5.9 per capita in 2019) and long shelf life [9-11].

The implementation of wheat flour substitutes or mimicry are desirable alternatives to achieve not only a decrease in calories, but also, to obtain a healthier nutritional profile in their composition $[12,13]$. Legumes and oilseeds such as soy, sunflower, barley, melon seeds, peanuts, hazelnuts, walnuts, sesame seeds, cashews, and almonds, are some alternative sources of flour $[9,10]$.

Also, food grade films, hydrogels, foams, and emulsifiers have been developed from vegetable proteins. Emulsions are capable of absorbing at the oil-in water interface or air-in water dispersion [7,14]. These are part of many processed food formulations. Proteins are widely used for encapsulation of active substances. The proteins are used as a wall material around the active principle droplet, manifesting advantages such as biocompatibility, biodegradability, amphiphilic and hydrophobic and functional properties [15]. Moreover, vegetable proteins can be combined with other polymers, forming a variety of complexes with different structures (e.g., double networks, mosaic textures and cross-linked structures) [7].

In emulsions, the emulsifying activity index, emulsifying stability index, droplet size, interfacial properties and viscosity parameters are used [1]. Other techniques that help to understand the structure of the emulsions and morphology of the particles, particle size, and colloid instabilities (e.g., flocculation, aggregation) are light microscopy, SEM, and dynamic or static light scattering [16]. Among the vegetable proteins emulsifiers options, we found mainly leguminous foodstuffs like soy, lupin, peas, and chickpeas, cereals like wheat, barley, corn, and rice and oil seed such as peanuts, sunflowers, canola, flaxseed, and sesame. [7,17].

In Mexico, the oilseed Prunus serotine is widely distributed, and can be found in 16 states of the Republic. Nowadays the production of the fruit goes to 467.96 tons per year [18,19]. However, only the fruit and leaves have been used since colonial times for nourishment and medicinal purposes [20]. While the seed is still of little economic value because of the waste of its nutritional benefits, since it is only consumed as a toasted snack, the main nutrients in its composition are unsaturated fatty acids $(89.9 \%)$ such as oleic, linoleic, and $\alpha$-eleostearic acid, crude fiber $(10.73 \pm 1.49 \%)$ and protein $(37.95 \pm 0.16 \%)$ with $88.12 \pm 0.72 \%$ of digestibility $[18,21]$. A protein value higher than other oilseeds like P. dulcis (19.91\%) and Arachis hypogaea (22.82\%), having lysine as the limiting amino acid. It has also been reported that digestibility values higher than $80 \%$ are related to an efficient amino acid bioavailability [18].

Its oil composition is also considered unique because of the significant content of $\alpha$-eleostearic acid [22]. This acid can be a nutraceutical ingredient because it is capable of providing beneficial health effects, including prevention and/or treatment of a disease [23]. Some studies report that it effectively suppresses growth of cancer cells, lowers serum lipid levels in mammals, and has been proposed as chemotherapeutic agent against breast cancer. P. serotine seed oil increase its potential as functional and nutraceutical ingredient [22]. 
Biotic and abiotic metabolites can contaminate crops and plant-based foods; therefore, toxins must be examined [24]. Cyanogenic glycosides occur in a wide range of food plant species, such as cassava root, apples, lima beans, passion fruit, and almonds [25]. Almonds contain amygdalin as a cyanogenic glycoside (a secondary metabolite) [26]. This metabolite produces hydrogen cyanide (HCN) when it is hydrolyzed. Its effects go from intoxication symptoms to neuropathic problems [27]. Nevertheless, the toasting process to which $P$. serotine seed is subjected as snack, helps to not produce amygdalin because of the temperature it is subjected to. The pericarp of P. serotine accumulates amygdalin, but it is acyanogenic because it lacks enzymes to release HCN [28]. In addition, it is devoid of oil content, as well as cyanide components [22]. All these circumstances, along with the fact that the seed has been used for human nutrition since ancient times, allow us to assume that it has little or no toxicity [28].

However, there are some treatments that can reduce or eliminate the risk of poisoning, whereby the focus in on removal of glycoside through washing and/or pressing the food, by enzymatic breakdown of the glycoside, destroying the enzyme or a combination of these methods [29].

From $P$. serotine seed, two valuable products can be obtained, namely $\alpha$-eleostearic acid with nutraceutical potential applications and the defatted seed with high protein content, which can be used for the development of biscuit products and concentrate protein for the stabilization of emulsions.

We have previously evaluated the study of $P$. serotine oil, so we are focusing on the second product and its derivates. Therefore, the aim was to evaluate P. serotine defatted flour without hydrogen cyanide risk in cookies and protein concentrate in emulsion stability.

\section{Materials and Methods}

P. serotine seeds were obtained from Xochimilco's market in Mexico City, Mexico. Wheat flour (Triticum spp.) and canola oil were purchased from a local food store in Monterrey, Nuevo Leon, Mexico. Whey protein concentrate (WPC, MB Pro-mix, 80\%) was food grade from Marquez Bros, International, Inc.-whey division, Hanford, CA. Solvents: hexane, n-propanol, boric acid, ethanol, phosphoric acid, and hydrochloric acid were of analytical grade (J.T. Baker reagents, Azcapotzalco, Mexico City, Mexico). The reagents sodium chloride, sodium hydroxide, sodium azide, sodium carbonate, sodium tartrate and copper sulphate were purchased from Development of Chemical Specialities in Monterrey, Nuevo Leon, Mexico. Picric acid was from Acce Microbiology in Guadalupe, Nuevo Leon, Mexico, and Coomassie brilliant blue G-250 from ThermoFisher Scientific, Mexico. Sucrose, Tris(hydroxymethyl)aminomethane, SDS, Folin \& Ciocalteu's and bovine serum albumin (BSA) were from Sigma-Aldrich, Mexico.

\subsection{P. serotine Defatted Flour}

A defatted flour was elaborated from the seeds of P. serotine (Scheme 1). Seeds were cracked open with a sterilized metal squeezer, washed with $2.5 \% \mathrm{NaCl}$ and distilled water $(1: 5, w / v)$ for 30 min with constant magnetic stirring, followed by scalding with hot water at $90^{\circ} \mathrm{C}$ for $5 \mathrm{~min}$, and drained for $7 \mathrm{~min}$, followed by drying for $1 \mathrm{~h}$ at $60^{\circ} \mathrm{C}$ in an oven with air circulation. Once dried, the oil was removed with a manual oil press (Kinetic, Henan Wecare Industry Co. Ltd., Jiaozuo, China) and the residue (ground seed) toasted to $100^{\circ} \mathrm{C}$ for $25 \mathrm{~min}$ [29]. Subsequently, the remaining oil was removed by constant magnetic stirring with hexane $(1: 5, w / v)$ to $25 \pm 2{ }^{\circ} \mathrm{C}$ for $1 \mathrm{~h}$. The ground seed was washed and filtered through Whatman paper No. 4 and dried in a hood extractor for 6 h. Finally, it was chopped in a blender and passed through a 70-mesh screen to obtain a P. serotine defatted flour [2]. 


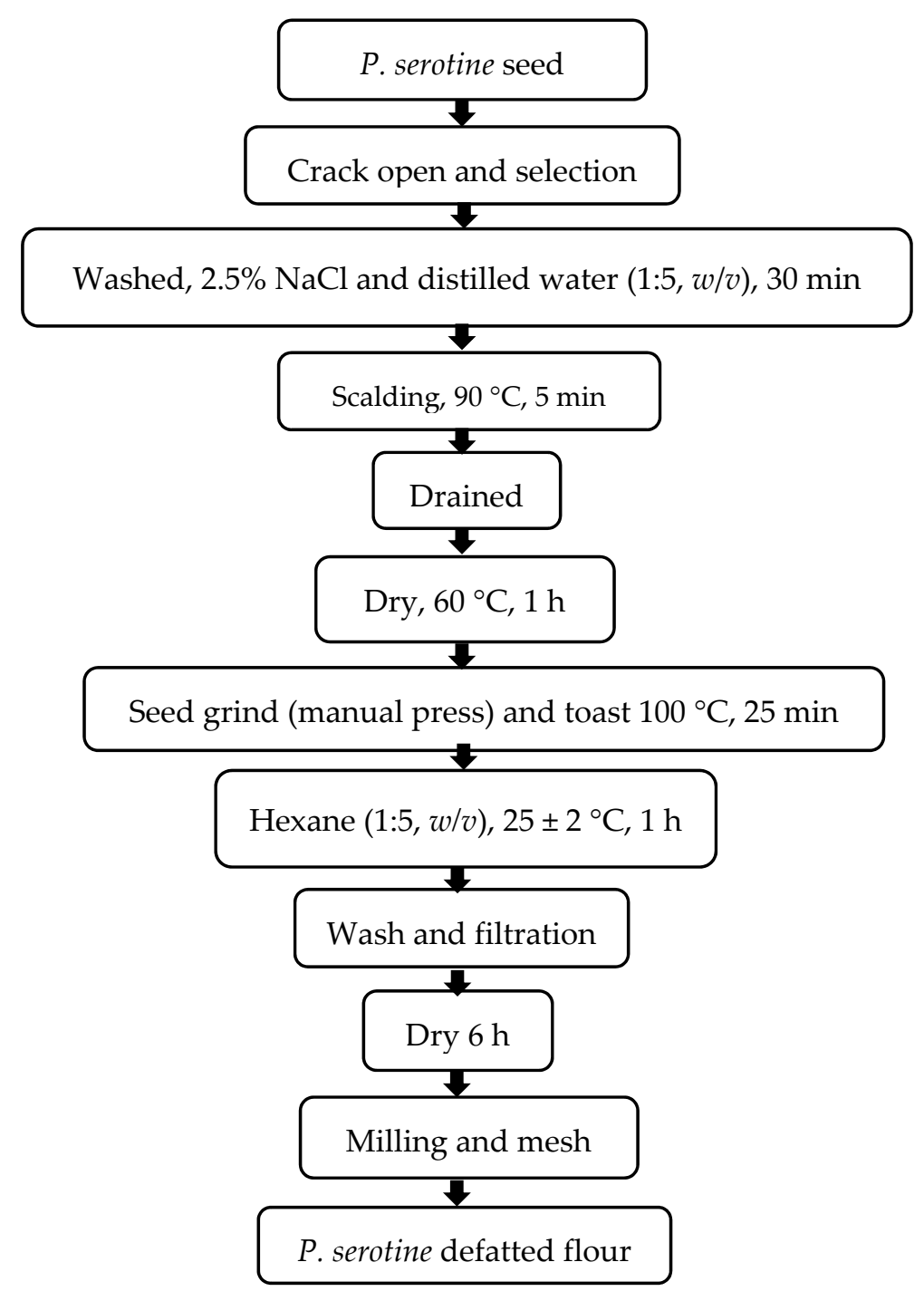

Scheme 1. Physical-chemistry process to obtain P. serotine defatted flour.

The flour yield was determined by the following formula:

$$
\text { Flour yield }(\%)=\frac{\text { Flour weight }(g)}{\text { Seed weight }(g)} * 100
$$

\subsection{Particle Size}

In order to measure the particle size of the P. serotine defatted flour, the methodology of Khor et al. [30] was used with some modifications. The flour was measured in a Mastersizer 3000 Hydro LV (Malvern Instruments Ltd., Worcestershire, UK) using the liquid unit. The particle size was evaluated through the volume-weight mean diameter $\left(\mathrm{D}_{4,3}\right)$ at $25 \pm 2{ }^{\circ} \mathrm{C}$, as Belorio et al. [31] report. Optical properties of the sample were defined as refractive index 1.37, isopropyl alcohol as dispersant, and an absorption of 0.1 . The results were expressed in $\mu \mathrm{m}$ as means \pm standard deviation. Wheat flour (Triticum spp.) was used as control.

\subsection{Chemical Composition}

Analysis were performed on P. serotine defatted flour by using Association of Official Analytical Chemistry [32] and compared with wheat flour (control). Moisture, ash, and crude fiber were evaluated gravimetrically (AOAC 14.006, AOAC 925.15 and AOAC 962.09, respectively). The Goldfish 
method (AOAC 920.36C) was used to determine the fat content. The protein was measured using the Kjeldahl method (AOAC 930.29) and total carbohydrates were determined by the difference using the following equation:

$$
\text { HC }(\%)=[100-(\text { protein }+ \text { lipids }+ \text { ash }+ \text { crude fiber })]
$$

\subsection{Grignard Test}

To verify that during the process of making $P$. serotine defatted flour, hydrocyanic acid (HCN) was eliminated, a qualitative test was used according to Castro and Rodriguez [33]. Picrosodic papers were prepared and then circles of filter paper (Whatman No. 4) were soaked with $1 \%$ picric acid solution and allowed to dry in the dark until they changed color to deep yellow. Once dried, they were impregnated with 10\% sodium carbonate and allowed to dry. Afterwards, they were fixed on the lid of amber bottles and two drops of $10 \%$ sodium carbonate were added, preventing it from dripping.

The P. serotine defatted flour was placed inside the jar to fill a third of it and covered quickly. The bottles were stored in the dark and after $24 \mathrm{~h}$, a reading was taken. As a control, only fractionated $P$. serotine seeds were used (without any treatment). If the paper's yellow color was maintained or it became light orange, there would be absolutely no problem in its consumption, but if it changed to intense orange or pink, it could only be consumed with caution and if the color became reddish or dark brown, it would not be safe to consume.

\subsection{Cookie Preparation}

Four variations of cookie recipe were made according to Jia et al. [34] with some modifications. The cookie dough formula is presented in Table 1 . The control recipe was $100 \%$ commercial wheat flour $(\mathrm{Fc})$ and the other four were 100, 75, 50, and 25\%, respectively, with P. serotine defatted flour (F1 to F4, respectively). Butter and sugar were mixed, then creamed with a Kitchen Aid mixer at low speed for one min. Vanilla essence and egg were added and mixed for one minute. In another bowl, all dry ingredients (flour, baking powder, and salt) were sifted and gradually added to the previous mix at low speed for $1 \mathrm{~min}$ and then medium speed for one $\mathrm{min}$. When all the ingredients were integrated and homogenized, the dough was wrapped in plastic and allowed to cool at $4{ }^{\circ} \mathrm{C}$ for $1 \mathrm{~h}$.

Table 1. Cookie dough formula.

\begin{tabular}{cc}
\hline Ingredients & Weight (g) \\
\hline Flour (Fc, F1, F2, F3, F4) & 150 \\
Baking powder & 3 \\
Salt & 3.5 \\
Butter without salt & 73 \\
Sugar & 66.6 \\
Egg & 25 \\
Vanilla essence & 2.5 \\
\hline
\end{tabular}

Fc corresponds to $150 \mathrm{~g}$ of wheat flour, F1 corresponds to $150 \mathrm{~g}$ of $P$. serotine defatted flour, F 2 corresponds to $112.5 \mathrm{~g}$ of P. serotine defatted flour and $37.5 \mathrm{~g}$ of wheat flour, F3 corresponds to $75 \mathrm{~g}$ of P. serotine defatted flour and $75 \mathrm{~g}$ of wheat flour and F4 corresponds to $37.5 \mathrm{~g}$ of P. serotine defatted flour and $112.5 \mathrm{~g}$ of wheat flour.

Once the dough had rested, it was kneaded and spread with a rolling pin and $2 \times 2 \mathrm{~cm}$ and $0.5 \mathrm{~cm}$ high square cookies were cut and, placed in an aluminum tray with waxed paper to prevent them from sticking. The oven was preheated at $160^{\circ} \mathrm{C}$ for $15 \mathrm{~min}$ and the cookies were baked for $12 \mathrm{~min}$ at the same temperature. After removal from the oven, the cookies were left to cool at room temperature $\left(25 \pm 2{ }^{\circ} \mathrm{C}\right)$. 


\subsection{Sensory Evaluation and Chemical Composition}

The evaluation was carried out in the Sensory Evaluation Laboratory of the Faculty of the College of Food Science at the Autonomous University of Nuevo Leon, Mexico. Fifty-five panelists (untrained) participated in the sensory test based on Jia et al. [34]. These individuals were seated at individual tables in different compartments. A 9-point hedonic scale was used $(1=$ extreme dislike, $5=$ neither like nor dislike, $9=$ extreme like) to evaluate the cookies texture, appearance, color, smell, taste, mouthfeel, aftertaste, and overall impression. Scores of five and higher for overall impressions were considered acceptable in this study. Cookies with 3-digit random number codes were randomly presented to the panelists, who were instructed to cleanse their palates with distilled water $\left(25^{\circ} \mathrm{C}\right)$ between sensory analyses. Chemical composition analysis (fat, protein, crude fiber and carbohydrate) involved quantification in the cookies with the highest score for the overall impression attribute, as specified in Section 2.3.

\subsection{Extraction of Soluble Proteins}

Proteins were extracted sequentially from P. serotine defatted flour according to the procedure described by Ramirez Pimentel et al. [35] and Raya Perez et al. [28], with the following solvents: distilled water (albumins), $0.5 \mathrm{M} \mathrm{NaCl}$ solution in $50 \mathrm{mM}$ Tris pH 8 (globulins), 55\% (v/v) 2-propanol (prolamins) and $0.1 \mathrm{M}$ boric acid with $0.5 \% \mathrm{SDS} \mathrm{pH} 8$ (glutelins).

The flour:solvent mixture (ratio 1:10, w/v) was stirred for $1 \mathrm{~h}$ at $25 \pm 2{ }^{\circ} \mathrm{C}$. The extracts were centrifuged (Hermle Z326, Labortechnik GmbH, Wehingen, Germany) at $13,000 \mathrm{~g}$ at $25 \pm 2{ }^{\circ} \mathrm{C}$ for $20 \mathrm{~min}$ and the supernatants filtered (Whatman No. 4). The extraction with each solvent was repeated on the same sample sequentially and the supernatants of the three extractions were combined.

\subsection{Soluble Protein Determination}

Soluble proteins were quantified from the soluble protein extractions as reported by Lopez Dellamary Toral [36] based on the Bradford [37] technique, with some modifications. Bovine serum albumin (BSA) was used as a standard $(0.05$ to $0.5 \mathrm{mg} / \mathrm{mL})$. The soluble protein fractions were diluted with $50 \mathrm{mM}$ Tris- $\mathrm{HCl}$ buffer at $\mathrm{pH} 7$, to obtain values within the standard range concentration. Albumin concentration was $0.49 \mathrm{mg} / \mathrm{mL}$, globulin $0.26 \mathrm{mg} / \mathrm{mL}$, prolamin $0.33 \mathrm{mg} / \mathrm{mL}$, and glutelin $0.24 \mathrm{mg} / \mathrm{mL}$. In microplates, $20 \mu \mathrm{L}$ of each extract was added in triplicate, using wells consecutively with $200 \mu \mathrm{L}$ of Bradford reagent $\left(0.01 \%\right.$ Coomassie Blue G-250, 4.75\% ethanol, $\left.85 \% \mathrm{H}_{3} \mathrm{PO}_{4}\right)$, allowing to stand for $2 \mathrm{~min}$. The samples were evaluated (microplate reader-Anthos 2020 version 2.0.5) at $620 \mathrm{~nm}$.

\subsection{Electrophoresis}

Protein patterns were analyzed according to Syros et al. [38] with some modifications based on Bio-Rad laboratories [39] using polyacrylamide gel electrophoresis (SDS-PAGE). Two glass plates were placed in the electrophoresis chamber, fixing them with plastic spacers and polyacrylamide gel (4-20\%) with a 10-well comb (Mini-PROTEAN TGX, Precast protein gels, Bio-Rad Laboratories, Inc. Irvine, CA, USA).

In gel rails, $20 \mu \mathrm{L}$ of each extraction of soluble protein fraction were placed (at the same previous concentrations) with distilled water. After electrophoresis, the gel was completely immersed in a fixing solution and washed three times for $10 \mathrm{~min}$ with distilled water. The gel was immersed and stirred in Coomassie blue dye solution (G-250) until bands were clearly evidenced. 


\subsection{Isoelectric Point ( $p I)$}

The isoelectric point of the P. serotine defatted flour was determined according to the theoretical determination of proteins and other macromolecules, through zeta potential ( $\zeta$-potential) which is the most direct characterization of the repulsion or attraction strength between their acid-base residues [40,41]. For this, a mixture of flour: deionized water in a 1:20 ratio $(w / v)$ at different $\mathrm{pH}$ with $0.1 \mathrm{~N} \mathrm{NaOH}$ and $0.1 \mathrm{~N} \mathrm{HCl}$ was vortexed for two minutes. Zetasizer Nano ZS90 light scattering equipment (Malvern Instruments, Worcestershire, England, UK) was used. The measures were in automatic mode using a universal immersion cell (ZEN 1002, Malvern Instrument, Worcestershire, UK) at $25^{\circ} \mathrm{C}$. The results were reported as the average of three separate injections, with three measures per injection. The averages of triplicate values were used as the values for zeta potential reported.

\subsection{Prunus serotine Protein Concentration (PsPC)}

To obtain PsPC the results obtained from the $\mathrm{p} I$ were taken as a basis. Variations of the procedure were undertaken to determine the one that was repeatable and had protein concentrate values $\geq 80 \%$ and $\leq 90 \%$. All procedures were initiated by mixing the P. serotine defatted flour for $1 \mathrm{~h}$ in vortex with distilled water at $\mathrm{pH} 11$ with $0.1 \mathrm{~N} \mathrm{NaOH}\left(25 \pm 2{ }^{\circ} \mathrm{C}\right)$, ratio $1: 20(w / v)$. Then the sample was isolated by centrifugation (Hermle Z326, Labortechnik $\mathrm{GmbH}$, Wehingen, Germany) at 13,000 $\mathrm{g}$ for $30 \mathrm{~min}$ and filtered through No. 4 Whatman paper to obtain two fractions (residue and supernatant).

In the first variation, up to two extractions of the residue obtained in the first part of the process were carried out with $5 \% \mathrm{NaCl}(1: 20, w / v)$, at two extraction times $\left(30 \mathrm{~min}\right.$ and $1 \mathrm{~h}$ ) in vortex at $25^{\circ} \mathrm{C}$, followed by centrifugation (Hermle Z326, Labortechnik $\mathrm{GmbH}$, Wehingen, Germany) at 13,000 $g$ for $30 \mathrm{~min}$ and filtered, again obtaining two fractions. The residue was analyzed utilizing the Kjeldhal method [32] to ensure the lowest protein loss in the process. The resulting supernatant was combined with the supernatant obtained in the first part, to subsequently acidify and solubilize the protein with $\mathrm{HCl}$ as shown in Scheme 1. The precipitate was stored until analysis at $-20^{\circ} \mathrm{C}$. The $\mathrm{pH}$ for acidification were 3.0, 3.7, and 4.5.

In the second variation, the residue of the first part was automatically discarded and the supernatant was acidified with $\mathrm{HCl}$ and left to rest for $30 \mathrm{~min}$. Finally, it was centrifuged and filtered under the previous conditions. The precipitate was collected and stored at $-20^{\circ} \mathrm{C}$ until use. Three acid $\mathrm{pH}$ values (3.0, 3.7, and 4.5) were tested (Scheme 2).

All final precipitates were analyzed according to proximal analysis via the Kjeldhal method based on AOAC 930.29 [32]. The yield was determined by the following equation:

$$
\text { Protein concentrate yield }(\%)=\frac{\text { Precipitate weight }(g)}{\text { Defatted flour weight }(g)} * 100
$$




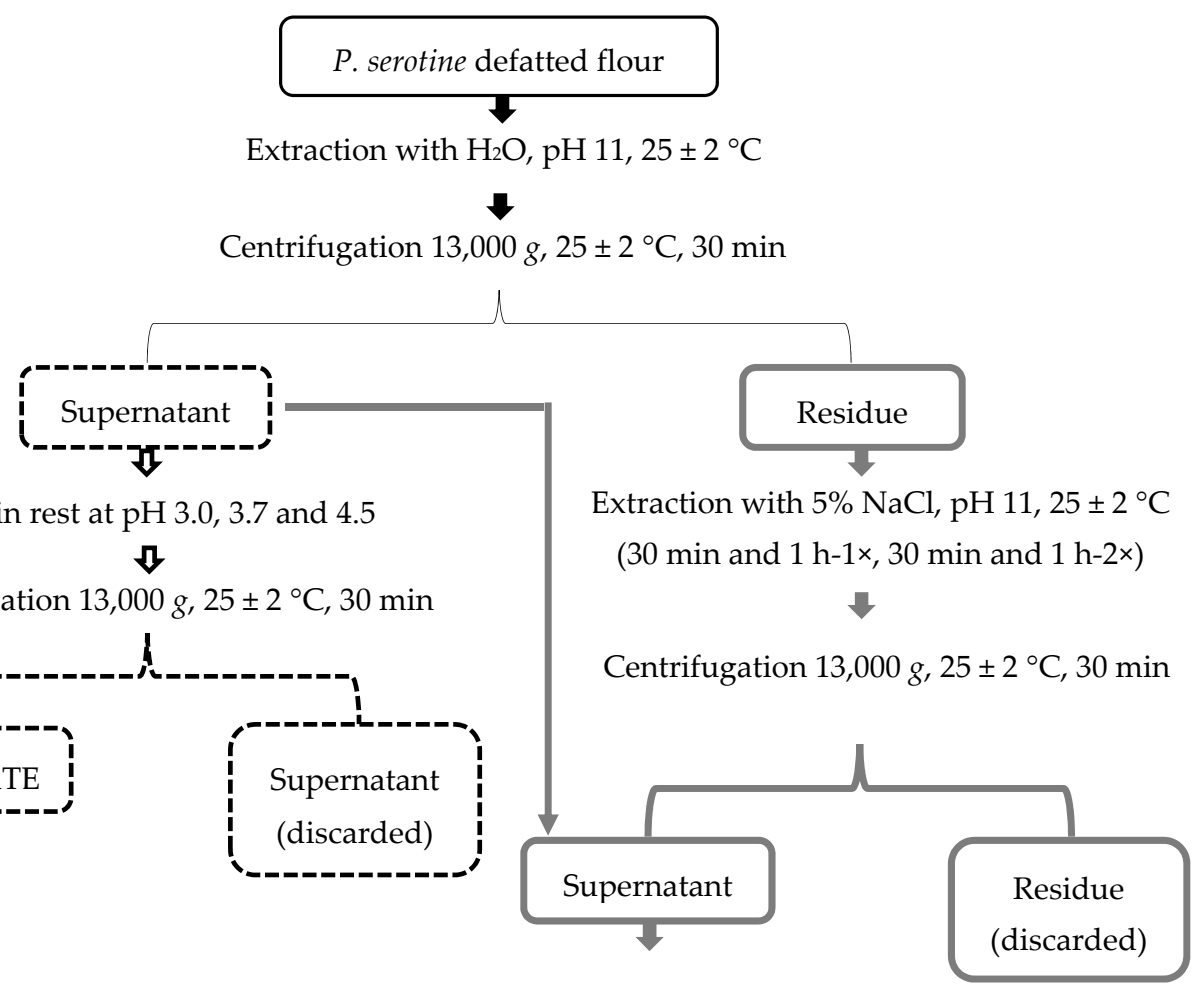

30 min rest at $\mathrm{pH} 3.0,3.7$ and 4.5

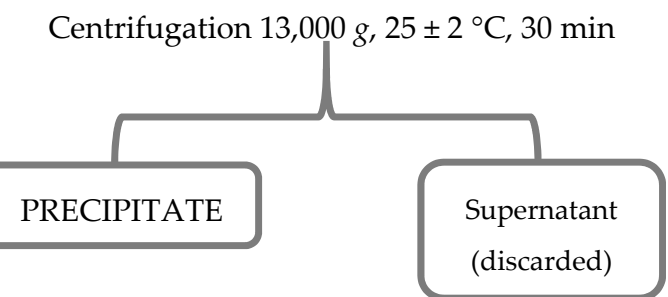

Scheme 2. The diagram in gray indicates the procedure for obtaining protein concentrate from the P. serotine defatted flour with $\mathrm{NaCl}$ treatment and acid $\mathrm{pH} .1 \times$ indicating that the extraction was performed once, and $2 \times$, that it was repeated twice. The black dots indicate the procedure for obtaining protein concentrate from the $P$. serotine defatted flour by direct acidification.

\subsection{Preparation of Emulsions}

The emulsifying agents ( $P$ SPC and whey protein concentrate) were prepared at $1 \% w / v$ in deionized water and solubilized with constant stirring. Then the sample was allowed to hydrate overnight at $4{ }^{\circ} \mathrm{C}$. Afterwards, $0.05 \%$ sodium azide was mixed to prevent microbial growth. Different amounts of canola oil $0.1,1,5,10$, and $20 \mathrm{~g}$ were added, to obtain a variety of mass fractions $(\phi=0.002,0.02,0.1$, 0.2 , and 0.4 ). The emulsions were mixed in a homogenizer (OMNI International GLH, Georgia, United States) at an initial speed of $1000 \mathrm{rpm}$ for $2 \mathrm{~min}$ and subsequently at $3000 \mathrm{rpm}$ for $3 \mathrm{~min}$. All emulsions were made in triplicate and stored at $25 \pm 2{ }^{\circ} \mathrm{C}$ for 18 days, and every three days, all the following analyzes were made. Whey protein concentrate (WPC) was used as a control $[42,43]$.

\subsection{Droplet Size Measurement}

Particle size was determined by integrated light scattering using a Mastersizer 3000 Hydro LV (Malvern Instruments Ltd., Worcestershire, UK). The emulsions were analyzed immediately after preparation in quintuplicate. Laser diffraction measures the particle size distribution (diameter equivalent to the volume) from the angular variation of the intensity of scattered light when the laser 
beam passes through the particles dispersed in solution. The data are then integrated based on the angular dispersion intensity, calculating the particle size through the Mie theory of light scattering. The droplet size of emulsions was evaluated through volume-surface mean diameter $\left(D_{3,2}\right)$ at $25 \pm 2{ }^{\circ} \mathrm{C}$ as Guo and Mu reports [1]. Optical properties of the sample were defined as refractive index 1.43 for PsPC and 1.46 for WPC, water as dispersant and an absorption of 0.1. The results were expressed as means \pm standard deviation [30].

\subsection{Emulsifying Activity Index and Emulsifying Stability Index (EAI and ESI)}

The EAI and ESI were assayed via the colorimetric method, previously reported by Guo and $\mathrm{Mu}$ [1]. Immediately after homogenizing each emulsion, $20 \mu \mathrm{L}$ from the bottom was taken and diluted with $5 \mathrm{~mL}$ of $0.1 \%$ SDS solution. It was vortexed for $5 \mathrm{~min}$ and, the absorbance was measured in a spectrophotometer (UV-Visible-Genesys 10s, Thermo scientific, Cambridge, MA, USA) at $500 \mathrm{~nm}$ [1]. The EAI and ESI were calculated using the following equations:

$$
\text { EAI }\left(\frac{m^{2}}{g}\right)=\frac{2 * 2.303 * A_{0} * \text { dilution factor }}{c * 1 *(1-\phi) * 10,000}
$$

where $c$ is the initial protein concentration which is $1 \% w / v, \phi$ is the oil weight fraction, dilution factor was 250 .

$$
\operatorname{ESI}(\min )=\frac{A_{0}}{A_{0}-A_{10}} * t
$$

where $A_{0}$ and $A_{10}$ are the absorbance of the diluted emulsions at 0 and $10 \mathrm{~min}$, respectively and, $t$ was $10 \mathrm{~min}$.

\subsection{Interfacial Protein Concentration}

According to Eichberg and Mokrasch [44] and Guo and Mu [1], interfacial protein concentration was quantified. Two milliliters of freshly prepared emulsions were diluted with $2 \mathrm{~mL}$ of $50 \%$ sucrose solution $(w / v)$ and vortexed for $5 \mathrm{~min}$ at $25 \pm 2{ }^{\circ} \mathrm{C}$. In a centrifuge tube, $2 \mathrm{~mL}$ of the solution were mixed with $7 \mathrm{~mL}$ of $5 \%$ sucrose solution $(w / v)$ and all samples were centrifuged (Spectrafuge $6 \mathrm{C}$, Labnet International, Inc., New York, NY, USA) at $3500 \mathrm{~g}$ for $30 \mathrm{~min}$ at $25 \pm 2{ }^{\circ} \mathrm{C}$. Once centrifuged, three phases were observed: the oil drops in the upper phase, an intermediate phase corresponding to the $5 \%$ sucrose solution, and the aqueous phase in the lower part of the tube. The tubes were frozen at $-40{ }^{\circ} \mathrm{C}$ for $24 \mathrm{~h}$ and then the upper layer of the oil was removed.

The proteins adsorbed from the oil phase were removed by adding $20 \mathrm{~mL}$ of $1 \%$ SDS $(w / v)$ solution. To determine the concentration of adsorbed protein, $1 \mathrm{~mL}$ of the sample was mixed with $3 \mathrm{~mL}$ of an alkaline copper reagent (A: $2 \% \mathrm{Na}_{2} \mathrm{CO}_{3}, 0.4 \% \mathrm{NaOH}, 0.16 \%$ sodium tartrate, and $1 \%$ SDS with $\mathrm{B}$ : $4 \% \mathrm{CuSO}_{4} \cdot 5 \mathrm{H}_{2} \mathrm{O}$, in a ratio of 100:1). The samples were vigorously stirred, and allowed to rest at $25 \pm 2{ }^{\circ} \mathrm{C}$ for $10 \mathrm{~min}$. Subsequently, $0.3 \mathrm{~mL}$ of $2 \mathrm{~N}$ Folin-Ciocaletu was added and allowed to stand for $45 \mathrm{~min}$ at $25 \pm 2{ }^{\circ} \mathrm{C}$. The absorbance was immediately measured at $660 \mathrm{~nm}$ in a spectrophotometer (UV-Visible-Genesys 10s, Thermo scientific, Cambridge, MA, USA) against a blank. Bovine serum albumin (BSA) was used as a standard. The interfacial protein concentration was calculated as:

$$
T\left(\frac{m g}{m^{2}}\right)=C_{a d} / S_{V}
$$

where $C_{a d}(\mathrm{mg} / \mathrm{mL})$ is the concentration of adsorbed protein and $S_{V}$ is the specific interfacial area $\left(\mathrm{m}^{2} / \mathrm{mL}\right.$ emulsion) of the emulsion droplets.

\subsection{Optical Microscopy}

The optical microscopy photographs were taken based on Huang et al. [45] with small modifications. Emulsions were mixed in vortex for $1 \mathrm{~min}$ prior to analysis. A drop of the emulsion was placed between 
the coverslip and microscope slide. The globules of the emulsions were examined and observed under bright field illumination with 40× objective lens on a Leica microscope (Leica DM500, 9435 Heerbrugg, Switzerland) along with the software Leica LAS EZ 2.0.0, Ltd., Application Suite (Leica Microsystems, 9435 Heerbrugg, Switzerland).

\subsection{Statistical Analysis}

Data from the replicated experiments were analyzed to determine whether the variances were statistically homogeneous, and the results were expressed as the mean \pm standard deviation (SD). Statistical comparisons were made by one-way variance analysis (ANOVA) followed by Tukey's test using Statgraphics centurion XVII Software. The difference between means was considered significant at $p<0.05$.

\section{Results and Discussion}

\subsection{Particle Size of Defatted Flour}

P. serotine defatted flour had a yield of $71.07 \pm 2.10 \%$. Its particle size $\left(\mathrm{D}_{4,3}\right)$ was $5.10 \pm 0.03 \mu \mathrm{m}$, which was minor for the commercial wheat flour (Triticum spp.) with $7.31 \pm 0.01 \mu \mathrm{m}$, making P. serotine flour 1.4 times smaller.

The AOAC 965.22 [46] mentioned that wheat flour must be able to pass through a No. 70 mesh $(212 \mu \mathrm{m})$ to be acceptable commercially, and P. serotine flour in the process of elaboration did pass through this mesh screen and its particle size was smaller than that of wheat flour (control).

It is already known that the particle size of wheat flour can influence cookie quality, but this can also be true for gluten-free flours. Belorio et al. [31] observed that cookies with smaller values of the elastic component $\left(G^{\prime}\right)$ correspond to flours with higher values of $\mathrm{D}_{4,3}$. Meanwhile, the biggest elastic values $\left(G^{\prime}\right)$ were found in doughs elaborated from finer flours.

\subsection{Chemical Composition}

The moisture in both flours passed the test mentioned in Codex Standard 152-1985 [47]. P. serotine defatted flour was 4.6 times less moisture than wheat flour (Table 2). It was not possible to remove all the oil contained in the P. serotine seed. After the separation process, $3.4 \%$ was quantified. Possibly because of the oil being bound to proteins contained in P. serotine, it also contains 5 times more protein and 1.5 times as much total fiber than wheat flour and 2 times less carbohydrates [48].

Table 2. Nutritional components of two flours.

\begin{tabular}{ccc}
\hline Component (\%) & P. serotine & Wheat $^{\mathbf{1}^{\text {(Triticum }} \text { spp.) }}$ \\
\hline Moisture & $2.58 \pm 0.09^{\mathrm{b}}$ & $11.92^{\mathrm{a}}$ \\
Ash & $5.36 \pm 0.24^{\mathrm{a}}$ & $0.47^{\mathrm{b}}$ \\
Fat & $3.36 \pm 0.31^{\mathrm{a}}$ & $0.98^{\mathrm{b}}$ \\
Protein & $50.94 \pm 0.64^{\mathrm{a}}$ & $10.33^{\mathrm{b}}$ \\
Crude Fiber & $4.03 \pm 0.27^{\mathrm{a}}$ & $2.7^{\mathrm{b}}$ \\
Carbohydrates & $36.31 \pm 1.09^{\mathrm{b}}$ & $76.31^{\mathrm{a}}$
\end{tabular}

The values are the average of five assays \pm standard deviations of the flours. Mean values labeled with a different letter in the same file are significantly different $(p<0.005) .{ }^{1}$ Wheat nutritional values were consulted on https://fdc.nal.usda.gov/fdc-app.html\#/food-details/168936/nutrients.

\subsection{Grignard Test}

Zumaeta Cordova and Gonzales Díaz [29] mentioned that the treatments that allow the release of hydrocyanic acid from glycosides and their subsequent elimination by drying or heating, are those that guarantee greater safety $\left(100^{\circ} \mathrm{C}\right.$ for $\left.25 \mathrm{~min}\right)$.

The experiment showed that in the control sample (fractionated seed without treatment), the paper impregnated with picric acid changed from yellow to deep orange, which indicated that the 
food could be consumed, but with caution. Meanwhile, the flour with treatment paper remained with the same yellow color. This indicated that there were no potential consumption problems (Figure 1).

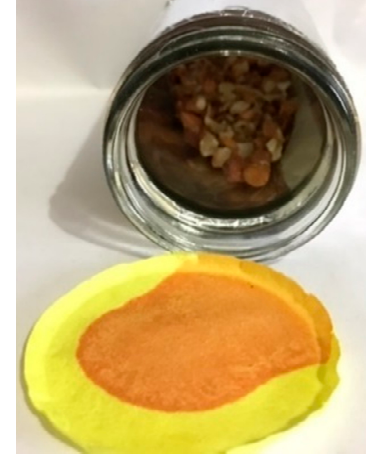

(a)

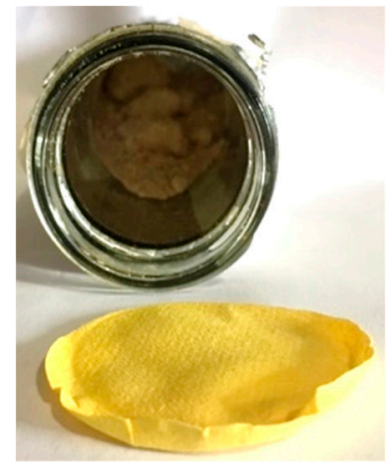

(b)

Figure 1. (a) P. serotine seed without treatment. (b) P. serotine defatted flour with treatment.

We believe that due to the low concentration of cyanogenic compounds, the consumption of $P$. serotine seeds has not caused any poisoning problems. In addition, the seed has been toasted for a long period of time prior to consumption.

According to Alveano Aguerrebere [20], there is no significant difference between the protein content of the seed in its toasted version $(37.95 \pm 0.16 \%)$, compared to when it is raw $(36.55 \pm 0.22 \%)$. Also, Garcia Aguilar et al. [18] mentioned that there is no significant difference in the values of in vitro protein digestibility of raw $(88.12 \pm 0.72 \%)$ and toasted $(89.40 \pm 1.32 \%)$ P. serotine seeds.

\subsection{Sensory Evaluation}

The effects of the addition of $P$. serotine defatted flour are shown in Table 3. A decrease in the scores of all sensory attributes and the overall impression of the cookies was found with the addition of $P$. serotine defatted flour. However, the maximum amount of $P$. serotine defatted flour accepted by the untrained panelists in the cookies was $75 \%$ (F2) based on the value obtained in the overall acceptability category though the formulation with $P$. serotine defatted flour showing the highest acceptability level was F3 with a substitution of $50 \%$.

Table 3. Effects of P. serotine defatted flour on sensory attributes of cookies.

\begin{tabular}{cccccc}
\hline Sensory Attributes & Fc & F1 & F2 & F3 & F4 \\
\hline Color & $7.38 \pm 2.01^{\mathrm{a}}$ & $4.49 \pm 2.01^{\mathrm{c}}$ & $5.93 \pm 2.03^{\mathrm{b}}$ & $6.96 \pm 1.49^{\mathrm{a}, \mathrm{b}}$ & $6.91 \pm 1.97^{\mathrm{a}, \mathrm{b}}$ \\
Smell & $7.43 \pm 1.78^{\mathrm{a}}$ & $4.81 \pm 1.99^{\mathrm{c}}$ & $6.04 \pm 2.03^{\mathrm{b}}$ & $6.59 \pm 1.46^{\mathrm{a}} \mathrm{b}$ & $6.48 \pm 1.77^{\mathrm{a}, \mathrm{b}}$ \\
Taste & $7.38 \pm 1.70^{\mathrm{a}}$ & $2.55 \pm 1.55^{\mathrm{c}}$ & $5.73 \pm 2.18^{\mathrm{b}}$ & $5.53 \pm 1.74^{\mathrm{b}}$ & $6.07 \pm 2.14^{\mathrm{b}}$ \\
Texture & $7.33 \pm 1.88^{\mathrm{a}}$ & $3.95 \pm 1.96^{\mathrm{c}}$ & $5.73 \pm 1.92^{\mathrm{b}}$ & $5.76 \pm 1.73^{\mathrm{b}}$ & $6.65 \pm 1.67^{\mathrm{a}, \mathrm{b}}$ \\
Appearance & $7.49 \pm 1.99^{\mathrm{a}}$ & $4.56 \pm 2.08^{\mathrm{c}}$ & $5.78 \pm 2.01^{\mathrm{b}}$ & $6.85 \pm 1.42^{\mathrm{a}}$ & $6.78 \pm 1.82^{\mathrm{a}, \mathrm{b}}$ \\
Mouthfeel & $7.33 \pm 1.76^{\mathrm{a}}$ & $3.16 \pm 1.61^{\mathrm{c}}$ & $5.39 \pm 2.34^{\mathrm{b}}$ & $5.69 \pm 1.76^{\mathrm{b}}$ & $6.05 \pm 2.04^{\mathrm{b}}$ \\
Aftertaste & $6.89 \pm 1.72^{\mathrm{a}}$ & $2.89 \pm 1.71^{\mathrm{c}}$ & $5.27 \pm 2.16^{\mathrm{b}}$ & $5.60 \pm 2.12^{\mathrm{b}}$ & $5.78 \pm 2.15^{\mathrm{b}}$ \\
Overall impression & $7.45 \pm 1.54^{\mathrm{a}}$ & $3.27 \pm 1.72^{\mathrm{c}}$ & $5.84 \pm 1.79^{\mathrm{b}}$ & $6.31 \pm 1.60^{\mathrm{b}}$ & $6.18 \pm 1.88^{\mathrm{b}}$ \\
\hline
\end{tabular}

The values are the average of fifty-five assay \pm standard deviations of the sensory attributes of cookies with P. serotine defatted flour and wheat flour. Mean values labeled with a different letter in the same file are significantly different $(p<0.005)$.

The results obtained in the evaluation show that the cookies that were made with 75 to $25 \%$ P. serotine defatted flour (F2 to F4) received a score greater than five in overall impression, making them acceptable. These cookies had greater acceptance compared to other cookies made with Californian almonds (P. dulcis), for which maximum acceptance was only $20 \%$ substitution, with a score of 5.25 in overall impression [34]. 


\subsection{Cookie Chemical Composition}

Based on the results obtained from the sensory test, a decision was made to carry out the chemical analysis on Fc cookies (100\% wheat flour) because it was preferred by the evaluators. Of the cookies made with P. serotine defatted flour, those substituted by 50 and 25\% (F3 and F4) were selected as a result of obtaining the highest score in overall impression (Table 4).

Table 4. Nutritional components in cookies with wheat and P. serotine defatted flour.

\begin{tabular}{cccc}
\hline Component (\%) & Fc & F3 & F4 \\
\hline Fat & $68.08 \pm 0.29^{\mathrm{a}}$ & $61.94 \pm 0.27^{\mathrm{a}}$ & $58.48 \pm 0.27^{\mathrm{a}}$ \\
Protein & $0.71 \pm 0.06^{\mathrm{c}}$ & $12.50 \pm 0.03^{\mathrm{a}}$ & $11.79 \pm 0.02^{\mathrm{b}}$ \\
Crude Fiber & $0.00 \pm 0.00^{\mathrm{a}}$ & $0.93 \pm 0.04^{\mathrm{a}}$ & $0.88 \pm 0.03^{\mathrm{a}}$ \\
Carbohydrates & $31.20 \pm 0.05^{\mathrm{a}}$ & $24.63 \pm 0.05^{\mathrm{c}}$ & $28.85 \pm 0.08^{\mathrm{b}}$ \\
\hline
\end{tabular}

The values are the average of three assays \pm standard deviations of cookies with wheat and P. serotine defatted flour. Mean values labeled with a different letter in the same file are significantly different $(p<0.005)$.

Cookies made with P. serotine defatted flour stood out for having fiber and for their protein content, up to 17 times higher than cookies with wheat flour $(\mathrm{Fc})$, as well as, for presenting 6.57 and $2.35 \%$ lower carbohydrates, and 6.14 and 9.6\% lower fat content (F3 and F4, respectively) than control cookies. In addition, it can be said that cookies made with 50 and $25 \%$ P. serotine defatted flour have a lower gluten content compared to control cookies, since almonds are the best vegetable sources of gluten-free protein and one of the most popular ingredients in the preparation of gluten-free foods, making them a healthy alternative for people suffering from celiac disease [49].

\subsection{Soluble Protein Determination}

From the P. serotine defatted flour $16.4 \pm 2.54 \mathrm{~g}$ soluble protein was extracted/100 $\mathrm{mL}$ of solution, which is equivalent to $32.15 \pm 0.49 \%$ of total protein content. The soluble protein profile was albumin $76.95 \pm 2.29 \%$, globulin $13.60 \pm 2.56 \%$, glutelin $6.16 \pm 0.99 \%$, and prolamin $3.29 \pm 0.37 \%$. The relative concentration of soluble protein with respect to insoluble proteins was 3.3:1 (Table 5). Raya Perez et al. [28], also quantified soluble protein in P. serotine and also reported albumin as the predominating fraction, followed by globulin, glutelin, and finally prolamin.

Table 5. Soluble protein content in P. serotine defatted flour.

\begin{tabular}{ccc}
\hline Soluble Protein & Protein Content $(\mathbf{m g} / \mathbf{m L})$ & $\begin{array}{c}\text { Fraction Content with Respect of } \\
\text { Total Soluble Protein (\%) }\end{array}$ \\
\hline Albumin & $126.09 \pm 3.74^{\mathrm{a}}$ & $76.95 \pm 2.29^{\mathrm{a}}$ \\
Globulin & $22.29 \pm 4.20^{\mathrm{b}}$ & $13.60 \pm 2.56^{\mathrm{b}}$ \\
Prolamin & $5.39 \pm 0.60^{\mathrm{d}}$ & $3.29 \pm 0.37^{\mathrm{d}}$ \\
Glutelin & $10.09 \pm 1.61^{\mathrm{c}}$ & $6.16 \pm 0.99^{\mathrm{c}}$ \\
\hline
\end{tabular}

The values are the average of three assays \pm standard deviations of the soluble proteins in P. serotine defatted flour. Mean values labeled with a different letter in the same column are significantly different $(p<0.005)$.

\subsection{Electrophoresis}

The SDS-PAGE patterns for P. serotine defatted flour is reported in Figure 2. The molecular weight of albumin varied in a range from 63 to $20 \mathrm{KDa}$ (lane 2 and 6). In globulins, it varied between 63 and $20 \mathrm{KDa}$ (lane 3 and 7), in prolamins, it ranged from 60 to $20 \mathrm{KDa}$ (lane 4 and 8), and in glutelins from 60 to $12 \mathrm{KDa}$ (lane 5 and 9). 


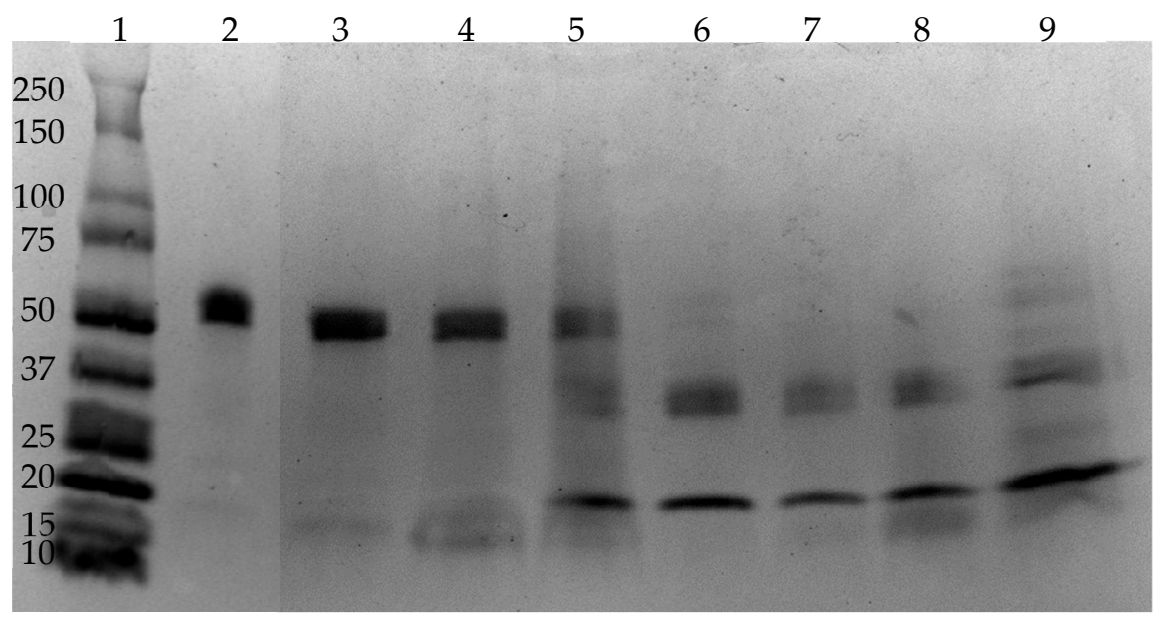

Figure 2. Soluble protein patterns of P. serotine defatted flour. 1. Molecular weight markers, lanes 2 to 5 (without 2-mercaptoethanol); 2. albumin; 3. globulin; 4. prolamin; 5 . glutelin. Lanes 6 to 9, as lanes 2 to 5 but with 2-mercaptoethanol.

The molecular weights obtained were similar to the ones reported by Raya Perez et al. [28]. Albumin weight varied between 65 and $20 \mathrm{KDa}$, globulin between 65 and $14 \mathrm{KDa}$ and prolamins and glutelins between 65 and $12 \mathrm{KDa}$, respectively.

Albumins and globulins are the main storage proteins of dicotyledonous plants (e.g., legumes and oilseeds), whereas prolamins and glutelins predominate in monocotyledonous plants (e.g., cereals). As expected of a nitrogen source, storage proteins are rich in asparagine (and aspartate), glutamine (and glutamate), and arginine [50], which is the case of P. serotine seed. According to Garcia Aguilar et al. [18] the seed contains $116.97 \mathrm{mg} / \mathrm{g}$ of asparagine, $273.73 \mathrm{mg} / \mathrm{g}$ of glutamine, and $87.42 \mathrm{mg} / \mathrm{g}$ of arginine (toasted version), the three amino acids showing the highest values.

Sze Tao and Sathe [2] have reported that pepsin is the most efficient protease hydrolyzing almond (P. dulcis) protein, especially for polypeptides with molecular weights from 15 to $42 \mathrm{KDa}$. Typically, pepsin hydrolysis produced polypeptides with 15 to $36 \mathrm{KDa}$, followed by 15 to $20 \mathrm{KDa}$ and some with 20 to $40 \mathrm{KDa}$. Therefore, $P$. serotine defatted flour protein may be useful in production of food protein hydrolysate and did not necessarily involve an additional process.

\subsection{Isoelectric Point (pI)}

The isoelectric point of an amino acid is the $\mathrm{pH}$ value at which the amino acid is doubly ionized or in zwitterion concentration and is deduced from the Henderson-Hasselbach equation, as the average of the $\mathrm{pK}$ values of the stages that form and decompose the zwitterion. The point of intersection of calibration curve with the $\mathrm{x}$-axis is $\mathrm{p} I$ value of protein [34,51].

As a result of the conductivity measurement at different $\mathrm{pH}$ of the $P$. serotine defatted flour, it was found that the specific $\mathrm{pI}$ for this oilseed was 3.7 (Figure 3). This value can be attributed to the high content of acidic amino acids present in the oilseed (aspartic acid $112.29 \mathrm{mg} / \mathrm{g}$ and glutamine $256.84 \mathrm{mg} / \mathrm{g}$ ), which influenced the low value of $\mathrm{pI}$ [17]. In addition, this value is within the optimum range for the precipitation of oil proteins such as peanuts $(4.0 \pm 0.25)$, coinciding with what other researchers have reported [52]. 


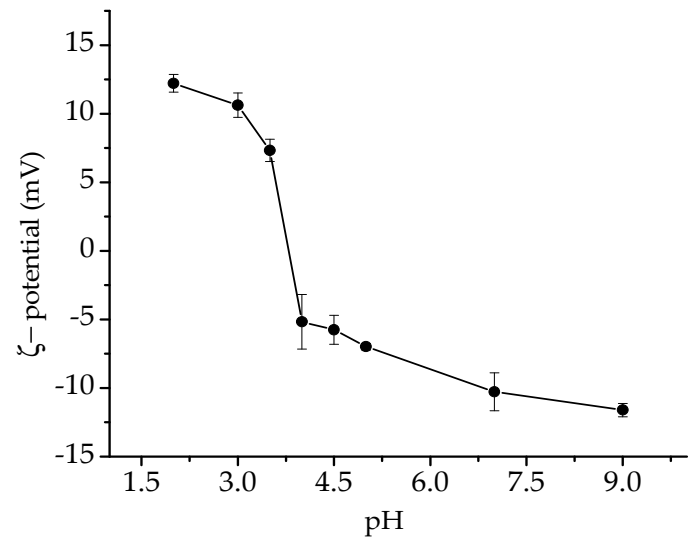

Figure 3. Isoelectric point $(\mathrm{p} I)$ of $P$. serotine defatted flour as a function change of concentration of hydrogen concentration.

\subsection{Prunus serotine Protein Concentration (PsPC)}

The P. serotine defatted flour was subjected to different treatments to obtain a process that is repeatable, standardized, and therefore reliable. The processes were adjusted and carried out as the results were obtained.

Usually to solubilize protein from oilseed meal, alkaline solutions are used. Solutions with a $\mathrm{pH}$ of 9 to 12 have higher protein yields. However, in values of $\mathrm{pH} 12$ and higher, isolates with better quality are not always obtained [53].

The salts increase the solubility through the salting-in process, whereby the counter ions cover the ionic charges of protein molecules [54]. NaCl is a solubilizing agent, and the combination of alkali and salt is often used to improve protein solubility [53]. Table 6 shows the results of treating the flour with an alkaline $\mathrm{pH}$ followed by the interaction with a saline solution at different numbers of extractions in order to extract and recover the highest protein content of the first residue of flour.

Table 6. Treatments to obtain protein content in P. serotine defatted flour.

\begin{tabular}{|c|c|c|c|c|c|}
\hline \multicolumn{6}{|c|}{ Protein Content in Final Precipitate of $P$. serotine Defatted Flour with $\mathrm{NaCl}$ and $\mathrm{pH}$ Adjustments. } \\
\hline Sample & $\begin{array}{c}\text { No. of } \\
\text { Extractions }\end{array}$ & $\begin{array}{c}\text { Time of } \\
\text { Extraction (min) }\end{array}$ & $\begin{array}{c}\text { Flour: } \mathrm{NaCl} \\
\text { Ratio (pH 11) }\end{array}$ & $\begin{array}{l}\mathrm{pH} \text { for Protein } \\
\text { Precipitation }\end{array}$ & $\begin{array}{c}\text { Protein Content } \\
(\%)\end{array}$ \\
\hline \multirow{5}{*}{$\begin{array}{c}\text { P. serotine } \\
\text { defatted flour }\end{array}$} & 1 & 30 & $1: 12$ & 4.5 & $73.47 \pm 0.92^{\mathrm{a}, \mathrm{b}}$ \\
\hline & 1 & 30 & $1: 12$ & 3.0 & $75.37 \pm 2.86^{\mathrm{a}}$ \\
\hline & 1 & 30 & $1: 6$ & 3.7 & $66.30 \pm 7.80^{b}$ \\
\hline & 1 & 30 & $1: 6$ & 3.0 & $70.78 \pm 4.50^{\mathrm{a}, \mathrm{b}}$ \\
\hline & 1 & 30 & $1: 3$ & 3.0 & $69.15 \pm 3.07^{\mathrm{a}, \mathrm{b}}$ \\
\hline \multicolumn{6}{|c|}{ Protein Content in Final Precipitate of P. serotine Defatted Flour with Direct Acidification. } \\
\hline Sample & $\begin{array}{c}\text { No. of } \\
\text { Extractions }\end{array}$ & $\begin{array}{c}\text { Time of } \\
\text { Extraction (min) }\end{array}$ & $\mathrm{pH}$ for Protei & Precipitation & $\begin{array}{c}\text { Protein Content } \\
(\%)\end{array}$ \\
\hline \multirow{3}{*}{$\begin{array}{c}\text { P. serotine } \\
\text { defatted flour }\end{array}$} & 1 & 30 & \multicolumn{2}{|c|}{4.5} & $63.99 \pm 6.63^{b}$ \\
\hline & 1 & 30 & \multicolumn{2}{|c|}{3.7} & $76.66 \pm 7.36^{a, b}$ \\
\hline & 1 & 30 & \multicolumn{2}{|c|}{3.0} & $81.99 \pm 6.96^{\mathrm{a}}$ \\
\hline
\end{tabular}

The values are the average of three assays \pm standard deviations of protein extractions from $P$. serotine defatted flour. Mean values labeled with a different letter in the same file are significantly different $(p<0.005)$.

The sample subjected to two extractions of one hour each with $\mathrm{NaCl}$ at a 1:20 $(w / v)$ ratio at $\mathrm{pH} 11$ had the lowest remaining protein in the residue $(13.30 \pm 0.39 \%)$, which would indicate that this process allows the collection of more protein in the supernatant of the treated sample.

The most common approach to recover solubilized proteins is by precipitating it with $\mathrm{pH}$ adjustment. In peanuts, some authors use $\mathrm{pH} 4.5[53,54]$, while other researchers mention that the 
optimum $\mathrm{pH}$ can be within the isoelectric region between $\mathrm{pH} 3.0$ and 5.0 [47]. Based on all these data, the following $\mathrm{pH}$ were used to precipitate the proteins of the supernatants: 4.5, 3.7, and 3.0.

The final protein content precipitated from the collected supernatant was not enough to reach the desired value of protein concentrate (whey protein concentrate $\geq 80 \%$ ). The resulting values were: $56.77 \pm 9.20(\mathrm{pH} 4.5), 66.96 \pm 1.21(\mathrm{pH} 3.7)$, and $72.02 \pm 5.01(\mathrm{pH} \mathrm{3.0)}$. This was attributed to the fact that at a high ionic strength, proteins can be almost completely precipitated from their solution because of dehydration in the protein molecules, thus reducing their solubility [53]. Therefore, the number and time of extraction was reduced in this, as well as in the flour: $\mathrm{NaCl}$ ratio (Table 6). At the same time, tests were carried out on the P. serotine defatted flour involving interaction only with an alkaline solution at $\mathrm{pH} 11$ and then the supernatant was acidified to identify, in which acidic $\mathrm{pH}$ was the most effective.

The results obtained when precipitating the supernatants at $\mathrm{pH} 3.0$ compared to other $\mathrm{pH}$ values (3.7 and 4.5) yielded a higher protein percentage. This was corroborated with the direct acidification process, which showed a concentrate value of $81.99 \pm 6.96 \%$.

The procedure was repeated two more times and results show that the treatment with direct acidification was the most effective. The average value of protein concentration in the final $P$. serotine defatted flour precipitate was $82.0 \%$.

Researchers have identified and quantified the amino acids present in P. serotine seed, as well as its total and soluble protein $[18,20,40]$. However, there are still no reports on the uses or applications of P. serotine protein concentrate, making this work one of the first in its findings.

\subsection{Droplet Size Measurement of Emulsions}

In Figure 4, it can be seen that emulsions with more oil content had the largest droplet size. As the days passed, the particle size increased when $\phi \geq 0.2$. In every PsPC emulsion, the maximum droplet size value was reached at different days, but it could be considered as average on day 10. While in WPC emulsions, the range of days to reach the maximum droplet size was more stable (between days 6 and 12), the particle size was more dispersed compared to the P. serotine protein.

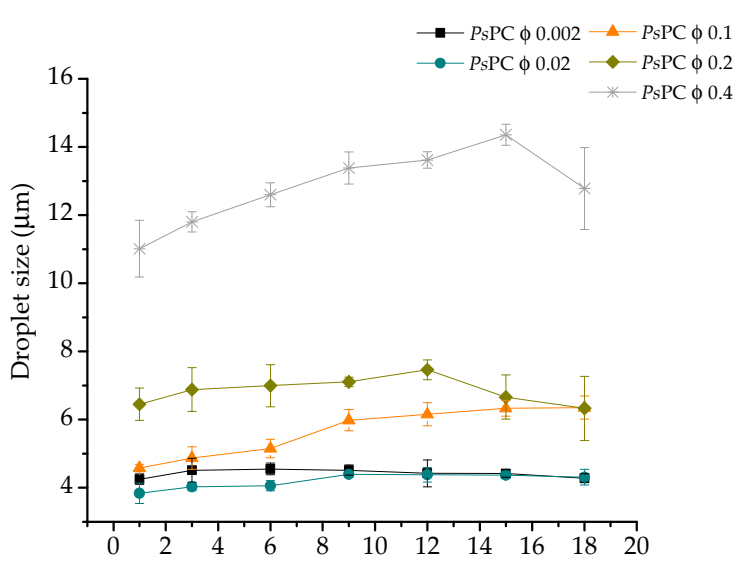

(a) Time (days)

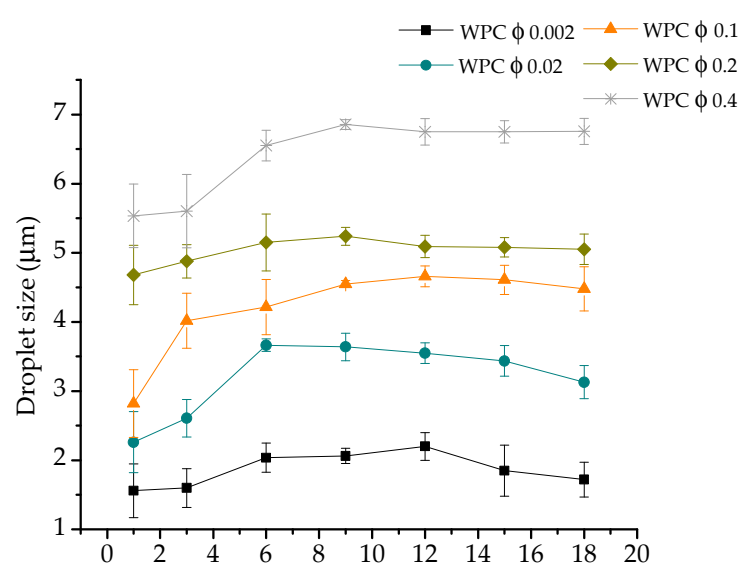

(b) Time (days)

Figure 4. Droplet size $\left(\mathrm{D}_{3,2}\right)$ of emulsions with $(\mathbf{a})$ protein concentrate $\left(P_{s} \mathrm{PC}\right)(1 \% w / v)$ compared to (b) whey protein concentrate (WPC) $(1 \% w / v)$ at different $\phi$.

The PsPC emulsion at $\phi 0.02$ presented a droplet size of $4.39 \pm 0.08 \mu \mathrm{m}$ as a maximum, becoming the smallest and more constant emulsion during the time of experiment, and for WPC, it was at $\phi$ 0.002 , with a value of $2.20 \pm 0.20 \mu \mathrm{m}$. In both the control (WPC) and PsPC emulsions, on the other hand, at $\phi 0.4$, the droplet size had the highest value of $6.88 \pm 0.11 \mu \mathrm{m}$ (day 9) and $14.36 \pm 0.31 \mu \mathrm{m}$ (day 15), respectively, during storage time because of coalescence.

A small droplet size is of interest in emulsion studies, because they are strongly correlated with high emulsion stability [16]. Authors such as Pandolfe [55] and Floury et al. [56] have reported that the increase of oil in emulsions led to a gradual increase of oil droplet sizes. Part of the effect may be due 
to the limitation of surfactants in emulsions, since as the oil content increases, the available proteins decreases, limiting the stabilizing benefits of the protein, thus favoring the coalescence of the oil drops, and therefore, increasing the diameter. We suggest that emulsion stability is due to the hydrophobicity of the polypeptide chain. The mean diameter of the droplets in food emulsions can vary from less than $0.2 \mu \mathrm{m}$ (for cream liqueurs) to greater than $100 \mu \mathrm{m}$ (for salad dressings), depending on the product [57].

\subsection{Emulsifying Activity Index and Emulsifying Stability Index (EAI and ESI)}

Compared with other particles, the protein particles have emulsifying properties and great potential to form soft particles [42]. The ability of a protein to form an emulsion can be defined as an emulsifying activity index (EAI), which determines the approximate amount of interfacial area that can be stabilized per unit amount of protein. Additionally, the stability of the emulsion over a specific time period is referred to as the emulsifying stability index (ESI) [58]. The EAI increased as did the mass fraction in PsPC emulsions (Figure 5). The effect was similar in the control emulsions.

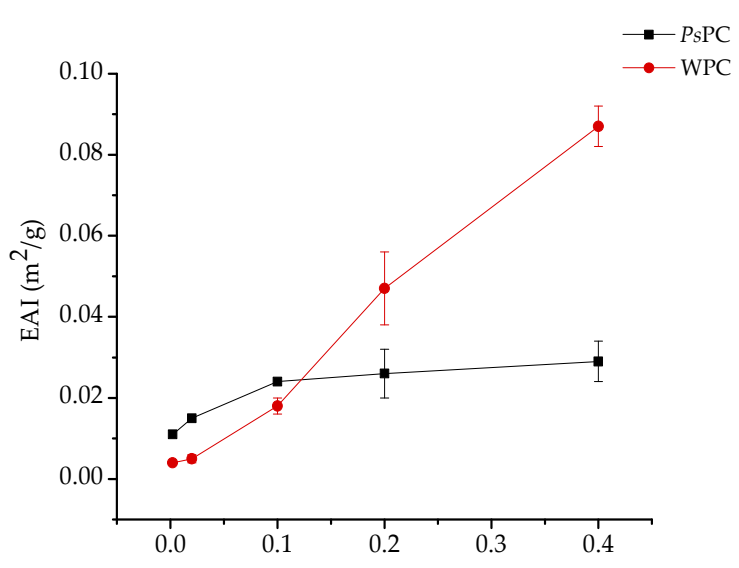

(a) Mass fraction $\phi(w / w)$

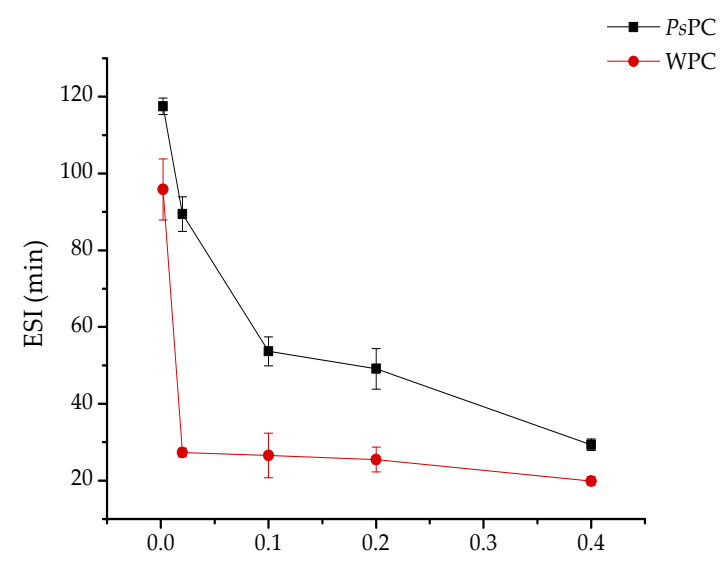

(b) Mass fraction $\phi(w / w)$

Figure 5. (a) Emulsifying activity index (EAI) and (b) emulsifying stability index (ESI) of PsPC emulsions compared with WPC at different $\phi$.

On the contrary, the stability time diminished as the mass fraction $(\phi)$ increased in ESI (Figure 5). In PsPC emulsions, ESI went from $117.50 \pm 2.17(\phi=0.002)$ to $29.34 \pm 1.48 \mathrm{~min}(\phi=0.4)$ and in WPC emulsions, from $95.83 \pm 7.95(\phi=0.002)$ to $19.87 \pm 1.08 \mathrm{~min}(\phi=0.4)$. For the control emulsions, less stability time was always reported compared to those of $P_{S} \mathrm{PC}$.

Different authors have mentioned similar characteristics in almond proteins, wheat gluten, and acidic subunits of soy (11S globulin) [2,59]. Guo and Mu [1] also got similar results when they studied emulsifying properties of sweet potato protein and found that at low protein concentrations $(<1 \%, w / v)$, the EAI values are greater, because it facilitates the formation of new droplets, and with the increase of oil, ESI value decreases. Nevertheless, at oil volumes $>35 \% v / v$, there is a marked increase in ESI, a phenomenon that has been reported also by Sun and Gunasekaran [60] for whey protein isolates.

EAI can be related with interfacial effect and low interaction with aqueous solutions. Our previous droplet size results can be associated with the EAI; as these indexes increased, the droplet size also increased. This can be attributed to the proteins that are surface active molecules with the capacity to improve the stability of oil-in-water emulsions, creating a protective membrane that generate repulsive interactions between oil droplets [16].

\subsection{Interfacial Protein Concentration}

The effect of interfacial protein concentration shows the oil drops phase separation after being centrifuged. The values suggest that emulsions were stable. When values of $\phi<0.2$ were used, it was difficult to separate the phases and reported the values. 
Table 7 shows the results of emulsions with $\phi 0.2$ and 0.4 . Control emulsions with WPC showed that as the volume of oil increases, the protein content at the interface is diminished.

Table 7. Interfacial protein concentration in $P_{S} P C$ and whey protein concentrate (WPC) emulsions.

\begin{tabular}{ccc}
\hline Sample & Mass Fraction $(\boldsymbol{\phi})$ & Interfacial Protein Concentration $\left.\mathbf{( m g} / \mathbf{m}^{\mathbf{2}}\right)$ \\
\hline \multirow{2}{*}{ PSPC } & 0.2 & $0.009 \pm 0.0$ \\
& 0.4 & $0.023 \pm 0.0$ \\
WPC & 0.2 & $0.015 \pm 0.0$ \\
& 0.4 & $0.014 \pm 0.0$ \\
\hline
\end{tabular}

The values are the average of three assay \pm standard deviations of interfacial protein concentration in $P_{s} P C$ and WPC emulsions.

The interfacial protein concentration in control emulsions was more constant, in contrast with PsPC, which showed a higher value as oil volume increased, allowing more stability.

\subsection{Optical Microscopy}

The microphotographs in function of PSPC and WPC are shown in Figures 6 and 7, respectively. The images reflect the results of droplet size analysis. It shows that as the mass fraction of emulsions increased, the droplet size also decreased and began to show coalescence. Guo and Mu [1] report similar results. The maximum droplet size can be seen between day 9 and 12 in both emulsions.
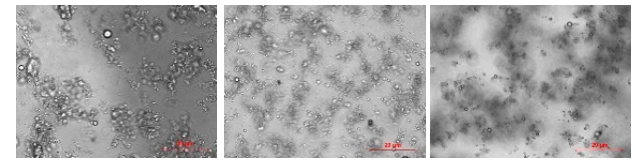

Time (days)

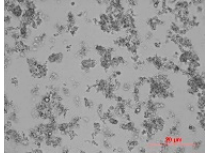

9

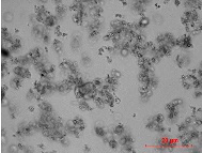

12

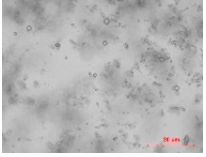

15

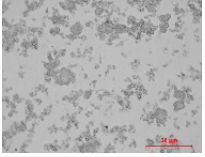

18

(a) $P S P C \phi 0.002$
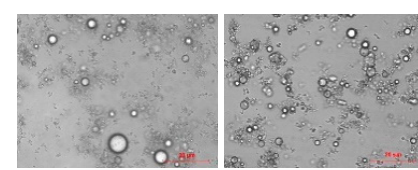

3
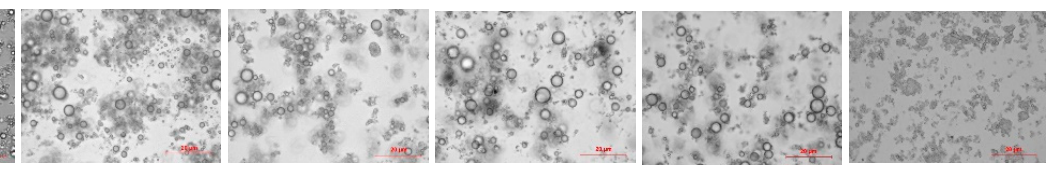

1

6

9

12

15

18

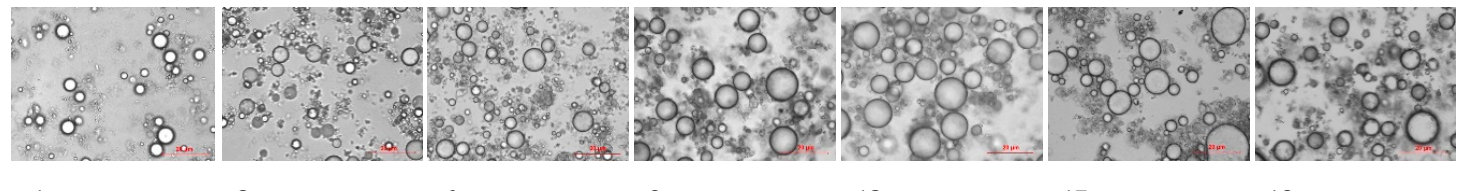

1

6

9

12

15

18

Time (days)

(c) $P s P C \phi 0.1$

Figure 6. Cont. 


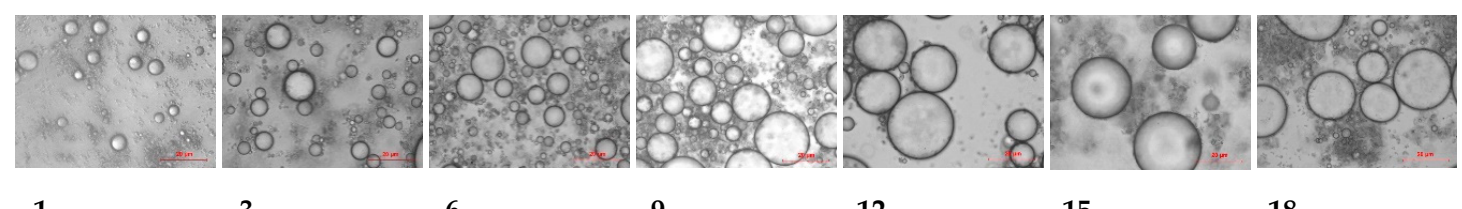

1

Time (days)
9
12

15

18

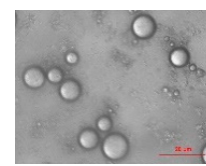

1

Time (days)

(d) $P_{s P C} \phi 0.2$

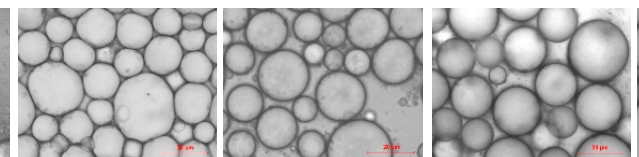

3

6

9

(e) $P_{S} \mathrm{PC} \phi 0.4$

Figure 6. (a-e) Microphotographs of $P_{S} P C$ emulsions at $40 \times$. Microphotographs show particle size in function of oil in aqueous phase.

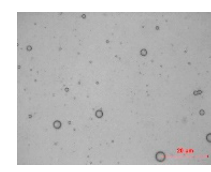

1

Time (days)

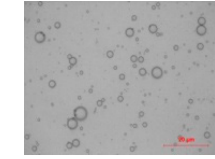

1

Time (days)

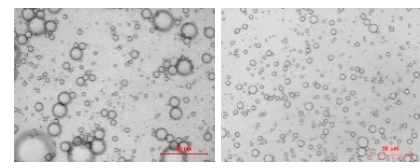

1

Time (days)

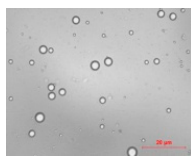

1

Time (days)

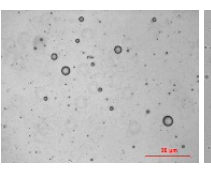

3

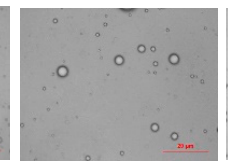

3

3

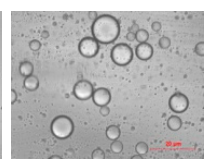

3
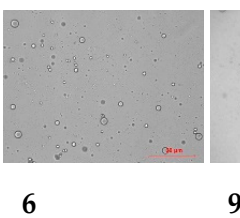

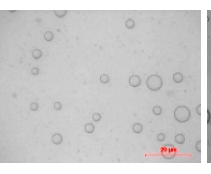

9

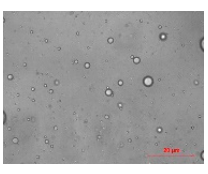

12

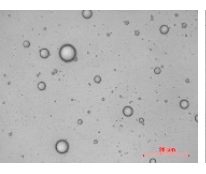

15

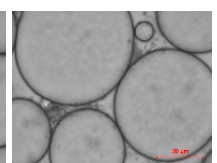

18

(a) WPC $\phi 0.002$

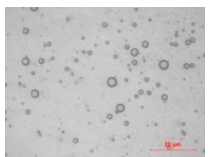

6

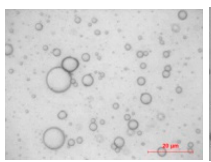

9

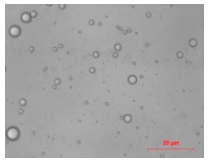

12

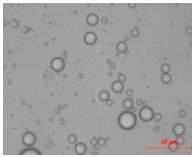

15

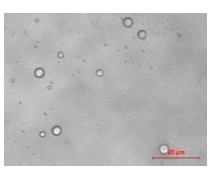

18

(b) WPC $\phi 0.02$
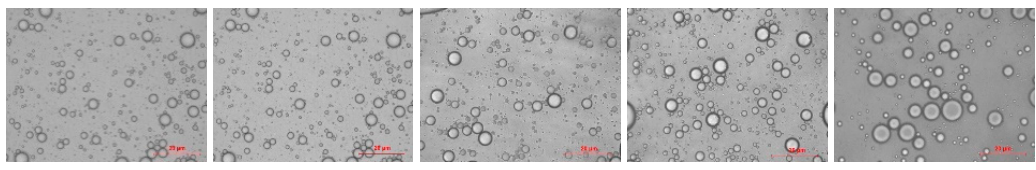

12

15

18

(c) WPC $\phi 0.1$

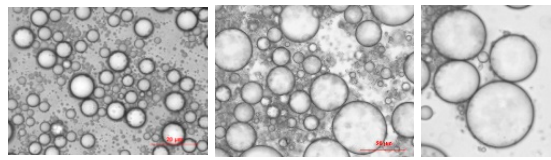

9

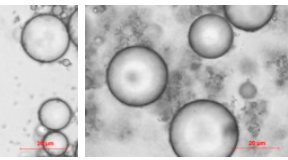

15

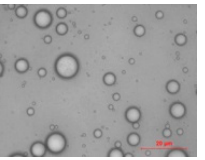

18
(d) WPC $\phi 0.2$

Figure 7. Cont. 


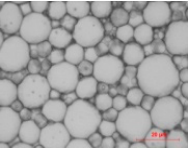

1

Time (days)

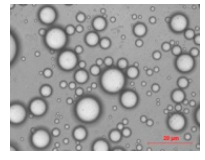

3

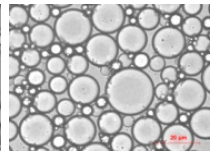

6

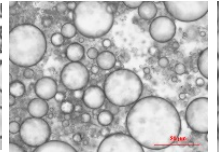

9

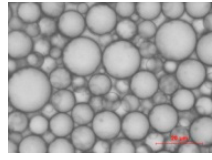

12

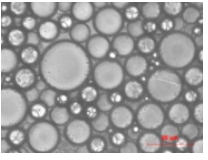

15

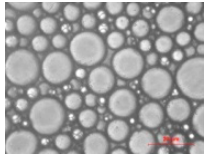

18

(e) WPC $\phi 0.4$

Figure 7. (a-e) Microphotographs of WPC emulsions at 40×. The particle size changes depending on the oil phase increase.

WPC and PSPC emulsions at their smallest mass fractions $(\phi=0.002$ and $\phi=0.02)$ showed more homogenization.

\section{Conclusions}

The $P$. serotine seed is an important source of protein and mainly contains albumin. P. serotine defatted flour can be used to replace wheat flour at 50\% in the preparation of cookies with acceptable sensory property. We believe that it is necessary to remove all cyanogenic compounds in flour of P. serotine. The Grignard test shows a positive reaction in flour without thermic treatment. The content of raw fiber in cookies was almost the same in all treatments. P. serotine flour purification can be a concentrated protein source with possible applications to stabilize emulsions.

The alkaline $(\mathrm{pH} 11)$ and acid ( $\mathrm{pH}$ 3.0) process showed a higher concentration of protein than the ionic force process as a function of the sodium chloride concentration. The protein concentrate is comparable to WPC in that it forms stable emulsions with oil content of less than $20 \%$ by weight, without changing the particle size during 18 days of storage.

Author Contributions: A.A.L.M., J.G.B.G., E.G.M., K.G.G.A. conceived and designed the experiments; A.A.L.M. and M.B.V. performed the experiments; J.G.B.G., A.A.L.M., M.B.V., K.G.G.A., S.A.G.R., and E.G.M. analyzed the data; J.G.B.G., K.G.G.A., and E.G.M. helped with reagents/plant materials/analysis tools; and A.A.L.M., M.B.V., J.G.B.G. and E.G.M. were involved in drafting the manuscript and revising it. All authors have approved the final version. All authors have read and agreed to the published version of the manuscript.

Funding: We thank CONACyT for the financial support through the project PN-2015-01-1470 and UANL-PAICyT CT723-19.

Acknowledgments: We would like to thank Consejo Nacional de Ciencia y Tecnología (CONACyT) for financially supporting through the project Problemas Nacionales-2015-01-1470 and financially supporting A.A.L.M. to obtain her Ph.D. (scholarship 611290), and Universidad Autónoma de Nuevo León (UANL) for financially supporting through the project PAICyT CT723-19.

Conflicts of Interest: The authors declare no conflict of interest. The funders had no role in the design of the study; in the collection, analysis, or interpretation of data; in the writing of the manuscript, or in the decision to publish the results.

\section{References}

1. Guo, Q.; Mu, T.H. Emulsifying properties of sweet potato protein: Effect of protein concentration and oil volume fraction. Food Hydrocoll. 2011, 25, 98-106. [CrossRef]

2. Sze Tao, K.W.C.; Sathe, S.K. Functional properties and in vitro digestibility of almond (Prunus dulcis L.) protein isolate. Food Chem. 2000, 69, 153-160. [CrossRef]

3. Hoffman, J.R.; Falvo, M.J. Protein-Which is Best? J. Sports Sci. Med. 2004, 3, 118-130. [PubMed]

4. Jiménez Yan, L.; Brito, A.; Cuzon, G.; Gaxiola, G.; García, T.; Taboada, G.; Soto, L.A.; Brito, R. Energy balance of Litopenaeus vannamei postlarvae fed on animal or vegetable protein based compounded feeds. Aquaculture 2006, 260, 337-345. [CrossRef]

5. Sawashita, N.; Naemura, A.; Shimizu, M.; Morimatsu, F.; Ijiri, Y.; Yamamoto, J. Effect of dietary vegetable and animal proteins on atherothrombosis in mice. Nutrition 2006, 22, 661-667. [CrossRef] 
6. Choi, Y.S.; Choi, J.H.; Han, D.J.; Kim, H.Y.; Lee, M.A.; Jeong, J.Y.; Chung, H.J.; Kim, C.J. Effects of replacing pork back fat with vegetable oils and rice bran fiber on the quality of reduced-fat frankfurters. Meat Sci. 2010, 84, 557-563. [CrossRef]

7. Lin, D.; Wei, L.; Alan, K.; Longtao, Z.; Baodong, Z.; Song, M. Interactions of vegetable proteins with other polymers: Structure-function relationships and applications in the food industry. Trends Food Sci. Technol. 2017, 68, 130-144. [CrossRef]

8. Alobo, A.P. Effect of sesame seed flour on millet biscuit characteristics. Plant Food Hum. Nutr. 2001, 56, 195-202. [CrossRef]

9. Ogunsina, B.S.; Radha, C.; Indrani, D. Quality characteristics of bread and cookies enriched with debittered Moringa oleifera seed flour. Int. J. Food Sci. Nutr. 2011, 62, 185-194. [CrossRef]

10. Wani, A.A.; Sogi, D.S.; Sing, P.; Khatkar, B.S. Influence of watermelon seed protein concentrates on dough handling, textural and sensory properties of cookies. J. Food Sci. Technol. 2013, 52, 2139-2147. [CrossRef]

11. Cookies and Crackers Europe Statista Market Forecast. Available online: https://www.statista.com/outlook/ 40100300/102/cookies-crackers/europe (accessed on 12 December 2019).

12. Giarnetti, M.; Paradiso, V.M.; Caponino, F.; Summo, C.; Pasqualone, A. Fat replacement in shortbread cookies using an emulsion filled gel based on inulin and extra virgin olive oil. LWT Food Sci. Technol. 2015, 63, 339-345. [CrossRef]

13. Swanson, R.B.; Perry, J.M. Modified oatmeal and chocolate chip cookies: Evaluation of the partial replacement of sugar and/or fat to reduce calories. Int. J. Consum. Stud. 2007, 31, 265-271. [CrossRef]

14. Berton Carabin, C.; Schroën, K. Towards new food emulsions: Designing the interface and beyond. Curr. Opin. Food Sci. 2019, 27, 74-81. [CrossRef]

15. Nesterenko, A.; Alric, I.; Silvestre, F.; Durrieu, V. Vegetable proteins in microencapsulation: A review of recent interventions and their effectiveness. Ind. Crops Prod. 2013, 42, 469-479. [CrossRef]

16. Tavernier, I.; Wijaya, W.; Van der Meeren, P.; Dewettinck, K.; Patel, A.R. Food-grade particles for emulsion stabilization. Trends Food Sci. Technol. 2016, 50, 159-174. [CrossRef]

17. Wang, R.; Tian, Z.; Chen, L. A novel process for microencapsulation of fish oil with barley protein. Food Res. Int. 2011, 44, 2735-2741. [CrossRef]

18. García Aguilar, L.; Rojas Molina, A.; Ibarra Alvarado, C.; Rojas Molina, J.I.; Vázquez Landaverde, P.A.; Luna Vázquez, F.J.; Zavala Sánchez, M.A. Nutritional value and volatile compounds of black cherry (Prunus serotina) seeds. Molecules 2015, 20, 3479-3495. [CrossRef]

19. Anuario Estadístico de la Producción Agrícola. Available online: http://infosiap.siap.gob.mx/aagricola_siap_ gb/ientidad/index.jsp (accessed on 16 October 2019).

20. Alveano Aguerrebere, I. Estudio Químico y Farmacológico de la Semilla de Prunus serotina. Master's Thesis, Universidad Autonoma de Querétaro, Querétaro, Mexico, November 2010.

21. Páez Reyes, L.M.; Sánchez Olarte, J.; Velasco Torres, M.; Álvarez Gaxiola, J.F.; Argumedo Macías, A. Propuesta de estrategia para el mejoramiento del cultivo de capulín en los municipios de Domingo Arenas, Calpan y San Nicolás de los Ranchos. Ra Ximhani 2013, 9, 109-119. [CrossRef]

22. Alveano Aguerrebere, I.; Rojas Molina, A.; Dave Oomah, B.; Drover, J.C.G. Characteristics of Prunus serotine seed oil. Food Chem. 2011, 124, 983-990. [CrossRef]

23. Santini, A.; Novellino, E. Nutraceuticals-shedding light on the grey are between pharmaceuticals and foods. Expert Rev. Clin. Pharmacol. 2018, 11, 545-547. [CrossRef]

24. Cimmino, A.; Andolfi, A.; Zonno, M.C.; Troise, C.; Santini, A.; Tuzi, A.; Vurro, M.; Ash, G.; Evidente, A. Phomentrioloxin: A phytotoxic pentasubstituted geranylcycloxentriol produced by Phomopsis sp., a potential mycoherbicide for Carthamus lanatus biocontrol. J. Nat. Prod. 2012, 75, 1130-1137. [CrossRef] [PubMed]

25. Cressey, P.; Saunders, D.; Goodman, J. Cyanogenic glycosides in plant-based foods available in New Zealand. Food Addit. Contam. Part A 2013, 30, 1946-1953. [CrossRef] [PubMed]

26. Vetter, J. Plant cyanogenic glycosides. Toxicon 2000, 38, 11-36. [CrossRef]

27. Lee, J.; Zhang, G.; Wood, E.; Castillo, C.R.; Mitchell, A.E. Quantification of amygdalin in nonbitter, semibitter, and bitter almonds (Prunus dulcis) by UHPLC-(ESI) QqQ MS/MS. J. Agric. Food Chem. 2013, 61, 7754-7759. [CrossRef] [PubMed]

28. Raya Pérez, J.C.; Aguirre Mancilla, C.L.; Tapia Aparicio, R.; Ramírez Pimentel, J.G.; Covarrubias Prieto, J. Caracterización de las proteínas de reserva y composición mineral de la semilla de capulín (Prunus serotina). Polibotánica 2012, 34, 203-215. 
29. Zumaeta Cordova, L.; Gonzales Díaz, G. Aceptabilidad y valor Nutricional de la Pasta de la hoja de yuca (Manihot esculenta) Utilizada en Distintos Productos Alimenticios. Bachelor's Thesis, Universidad Nacional de la Amazonia Peruana, Iquito, Peru, 11 August 2014.

30. Khor, Y.P.; Kosh, S.P.; Long, K.; Long, S.; Syed Ahmad, S.; Tan, C. A comparative study of the physicochemical properties of a virgin coconut oil emulsion and commercial food supplement emulsion. Molecules 2014, 19, 9187-9202. [CrossRef]

31. Belorio, M.; Sahagún, M.; Gómez, M. Influence of flour particle size distribution on the quality of maize gluten-free cookies. Foods 2019, 8, 83. [CrossRef]

32. Association of Official Analytical Chemist (AOAC). Official Methods of Analysis of International, 16th ed.; AOAC: Rockville, Maryland, MD, USA, 1998.

33. Reacción de Grignard para Detectar Compuestos del Ácido Cianhídrico en Sorgo. Available online: https: //inta.gob.ar/documentos/reaccion-de-grignard-para-detectar-compuestos-del-acido-cianidrico-en-sorgo (accessed on 28 August 2018).

34. Jia, C.; Huang, W.; Abdel-Samie, M.A.-S.; Huang, G.; Huang, G. Dough rheological, mixolab mixing, and nutritional characteristics of almond cookies with and without xylanase. J. Food Eng. 2011, 105, 227-232. [CrossRef]

35. Ramírez Pimentel, J.G.; Herrera Herrera, A.; Aguirre Mancilla, C.L.; Covarrubias Prieto, J.; Iturriaga de la Fuente, G.; Raya Pérez, J.C. Caracterización de las proteínas de reserva y contenido mineral de semilla de melón (Cucumis melo L.). Rev. Mex. Cienc. Agríc. 2016, 7, 1667-1678. [CrossRef]

36. López Dellamary Toral, F.A. Aislamiento y Caracterización de Proteinas de las Semillas Maduras de Enterolobium cyclocarpum para su Aprovechamiento Alimenticio. Ph.D. Thesis, Universidad de Colima, Colima, México, November 2000.

37. Bradford, M.C. A rapid and sensitive method for the quantitation of microgram quantities of protein utilizing the principle of protein dye binding. Anal. Biochem. 1976, 72, 248-254. [CrossRef]

38. Syros, T.; Yupsanis, T.; Economou, A. Fractionation and electrophoretic patterns of storage proteins of Ebenus cretica. A preliminary survey as a tool in taxonomy. Biol. Plant. 2003, 46, 435-443. [CrossRef]

39. Mini-PROTEAN Tetra Cell. Available online: https://www.bio-rad.com/webroot/web/pdf/lsr/literature/ 10007296D.pdf (accessed on 5 September 2018).

40. Feng, X.; Dai, H.; Ma, L.; Yu, Y.; Tang, M.; Li, Y.; Hu, W.; Liu, T.; Zhang, Y. Food-grade gelatin nanoparticles: Preparation, characterization, and preliminary application for stabilizing pickering emulsions. Foods 2019, 8, 479. [CrossRef] [PubMed]

41. Xiong, T.; Ye, X.; Su, Y.T.; Chen, X.; Sun, H.; Li, B.; Chen, Y. Identification and quantification of proteins at adsorption layer of emulsion stabilized by pea protein isolates. Colloids Surf. B 2018, 171, 1-9. [CrossRef]

42. Sillero, A.; Maldonado, A. Isoelectric point determination of proteins and other macromolecules: Oscillating method. Comput. Biol. Med. 2006, 36, 157-166. [CrossRef] [PubMed]

43. Yesiltas, B.; Sorensen, A.M.; García Moreno, P.J.; Anankanbil, S.; Guo, Z.; Jacobsen, C. Combination of sodium caseinate and succinylated alginate improved stability of high fat fish oil-in-water emulsions. Food Chem. 2018, 255, 290-299. [CrossRef]

44. Eichberg, J.; Mokrasch, L.C. Interference by oxidized lipids in the determination of protein by the Lowry procedure. Anal. Biochem. 1969, 30, 386-390. [CrossRef]

45. Huang, X.; Kakuda, Y.; Cui, W. Hydrocolloids in emulsions: Particle size distribution and interfacial activity. Food Hydrocoll. 2011, 15, 533-542. [CrossRef]

46. Norma del Codex para la Harina del Trigo. Available online: file://C:/Users/FAM\%20TT/Downloads/CXS 152s\%20(1).pdf (accessed on 12 March 2017).

47. CODEX-STAN-152-1985. Norma del Codex para la Harina de Trigo. (Rev.1 -1995). Available online: http: //www.colpos.mx/bancodenormas/ninternacionales/CODEX-STAN-152-1985.pdf (accessed on 5 April 2017).

48. USDA. U.S. Department of Agriculture. Available online: https://fdc.nal.usda.gov/fdc-app.html\#/fooddetails/168936/nutrients (accessed on 20 January 2019).

49. CINECA IRIS Institutional Research Information System. Available online: http://hdl.handle.net/11369/363087 (accessed on 15 May 2019).

50. González Pérez, S.; Arellano, J.B. Vegetable protein isolates. In Handbook of Hydrocolloids, 2nd ed.; Phillips, G.O., Williams, P.A., Eds.; Woodhead Publishing: Salamanca, Spain, 2009; pp. 383-419. 
51. UNSA Investiga Repositorio Institucional. Available online: http://repositorio.unsa.edu.pe/handle/UNSA/ 6553 (accessed on 12 October 2017).

52. Ferreyra, J.C.; Kuskoski, E.M.; Bordignon Luiz, M.T.; Barrera Arellano, D.; Fett, R. Propiedades emulsificantes y espumantes de las proteínas de harina de cacahuate (Arachis hypogaea Lineau). Grasas Aceites 2007, 58, 264-269.

53. Arntfield, S.D. Proteins from Oil-Producing Plants, 2nd ed.; Woodhead Publishing: Winnipeg, MB, Canada, 2018; pp. 146-167.

54. Universidad Nacional de Quilmnes. Available online: http://ufq.unq.edu.ar/Docencia-Virtual/BQblog/ Salting-in-Salting-out-precipitacion-solventes (accessed on 2 September 2018).

55. Pandolfe, W.D. Effect of premix condition, surfactant concentration, and oil level on the formation of oil-in-water emulsions by homogenization. J. Disper. Sci. Techol. 1995, 16, 633-650. [CrossRef]

56. Floury, J.; Desrumaux, A.; Lardieres, J. Effect of high-pressure homogeniztion on droplet size distributions and rheological properties of model oil-in-water emulsions. Innov. Food Sci. Emerg. Technol. 2000, 1, 127-134. [CrossRef]

57. McClements, D.; Decker, E. Lipid Oxidation in Oil-in-Water Emulsions: Impact of Molecular Environment on Chemical Reactions in Heterogeneous Food Systems. J. Food Sci. 2000, 65, 1270-1282. [CrossRef]

58. Tirgar, M.; Silcock, P.; Carne, A.; Birch, E.J. Effect of extraction method on functional properties of flaxseed protein concentrates. Food Chem. 2017, 215, 417-424. [CrossRef] [PubMed]

59. Liu, M.; Lee, D.S.; Damodaran, S. Emulsifying properties of acidic subunits of soy 11 S globulin. J. Agric. Food Chem. 1999, 47, 4970-4975. [CrossRef] [PubMed]

60. Sun, C.H.; Gunasekaran, S. Effects of protein concentration and oil phase volume fraction on the stability and rheology of menhaden oil-in water emulsions stabilized by whey protein isolate with xanthan gum. Food Hydrocoll. 2009, 23, 165-170. [CrossRef]

(C) 2019 by the authors. Licensee MDPI, Basel, Switzerland. This article is an open access article distributed under the terms and conditions of the Creative Commons Attribution (CC BY) license (http://creativecommons.org/licenses/by/4.0/). 